\title{
Historic Roots of Modern Residential Segregation in a Southwestern Metropolis: San Antonio, Texas in 1910 and 2010
}

\author{
Rebecca J. Walter ${ }^{1, *}$, Nathan Foote ${ }^{2}$, Hilton A. Cordoba ${ }^{3}$ and Corey Sparks ${ }^{4}$ \\ 1 Urban and Regional Planning Program, College of Architecture, Construction and Planning, \\ The University of Texas at San Antonio, One UTSA Circle, San Antonio, TX 78249, USA \\ 2 Edward J. Bloustein School of Planning and Public Policy, Rutgers, The State University of New Jersey, \\ 33 Livingston Ave., New Brunswick, NJ 08901, USA; nathan.foote@rutgers.edu \\ 3 Department of History, Geography and Philosophy, College of Liberal Arts, University of Louisiana at \\ Lafayette, P.O. Box 43605, Lafayette, LA 70504, USA; hac9361@louisiana.edu \\ 4 Department of Demography, College of Public Policy, The University of Texas at San Antonio, \\ One UTSA Circle, San Antonio, TX 78249, USA; corey.sparks@utsa.edu \\ * Correspondence: Rebecca.Walter@utsa.edu; Tel.: +1-210-458-3013
}

Academic Editor: Jesús Manuel González Pérez

Received: 19 April 2017; Accepted: 27 May 2017; Published: 1 June 2017

\begin{abstract}
This study seeks to understand the historic roots of modern segregation by comparing residential racial patterns in the city of San Antonio over time. The year 1910 is recreated for San Antonio by georeferencing and digitizing historic Sanborn maps and aligning residential structures with historical census and city directory race data for the head of household. The historical point data are aggregated to the census block level and compared to 2010 householder race data by calculating the two most common dimensions of residential segregation: evenness (dissimilarity and Theil's index) and exposure (isolation and interaction). The findings reveal that by 1910 San Antonio was already a remarkably segregated city and the original patterns of residential segregation resemble contemporary San Antonio. Particularly, residential racial segregation in the Hispanic concentrated southwestern portion of the city has increased over time resulting in an exceptionally racially divided metropolis.
\end{abstract}

Keywords: residential segregation; race; San Antonio; Hispanic

\section{Introduction}

Residential segregation, the degree to which two or more groups live apart from one another [1], is a dominant feature of the urban landscape in America. The rise of residential segregation, by both race and income, over the last several decades has been frequently highlighted by scholars. A wealth of research exists examining the determinants and consequences of residential segregation [2-7] and policies over the last century have resulted in the perpetuation of poor minority distressed neighborhoods in inner cities across the nation [8-11].

What about the origins of residential segregation prior to twentieth century factors and policies that have perpetuated it? The historic roots of this topic are important. Although the factors that perpetuate segregation may be different than those that initially generated it, an understanding of original segregation patterns compared to contemporary patterns can help guide effective strategies to combat residential segregation [12]. Furthermore, while the segregation of other minority groups has not received as much attention, due perhaps to the "hypersegregation" of Black neighborhoods compared to other groups [13], varying degrees of segregation of various minority groups have been documented [13-18]. More recently, the segregation of Hispanics from Whites and Blacks has 
become of increasing interest as individuals of Hispanic descent make up more of the population in the United States, and as the Hispanic population moves into a variety of urban areas $[15,17,19,20]$. One urban area that has been a consistent destination for individuals of many ethnic groups is the southwestern city of San Antonio. These influxes have led to a pattern of segregation in San Antonio in which immigrants from Latin America, Korea, and Vietnam, as well as Blacks, live in central city enclaves, while those of European descent live in suburban areas [16]. This situation raises the question of how long these patterns have existed.

This study seeks to understand the historic roots of modern segregation in the southwestern cosmopolis of San Antonio by examining the two most common dimensions of residential segregation in the city of San Antonio, one of the most residentially segregated cities in the nation $[13,16,21]$. Historical residential neighborhoods around the city core are reconstructed digitally by georeferencing and digitizing historic Sanborn maps which are aligned with historic city directory and census data to address the following research questions: (1) What was the pattern of residential segregation in San Antonio's city core in 1910 and how has this configuration changed over the last century?; and (2) Is the spatial distribution of residential segregation in the original 1910 city core similar to the central city in 2010? It is important to note that the first question only compares the urban core, the original two square miles of historic San Antonio which is centered on Main Plaza and San Fernando Cathedral. The second research question compares the central city of 1910 to 2010, which is a much larger area in 2010 (181 square miles defined by the Interstate 410 loop).

This study contributes to the existing literature by uncovering the patterns of residential segregation over one hundred years ago by using historical data to create a unique geodatabase. This database allows for detailed analysis of residential settlement patterns that provide insight into the past to establish the foundation for answering research questions about the perpetuation of residential segregation over time. Only a few studies have examined residential segregation patterns in the early twentieth century $[22,23]$ and comparing patterns over a century is unique to the literature. Furthermore, the growing importance of non-Black minorities in the urban landscape of the United States makes the historical analysis in San Antonio useful to future scholarship on the segregation of Hispanics, the largest and fastest growing minority group in America.

\section{Theoretical Background}

Chung and Brown [24] discuss four major theories, or frameworks, for understanding why residential segregation occurs and how it propagates. The spatial assimilation framework has the earliest roots of the four theories, since it rests on Chicago School ideas about neighborhood change and segregation. Assimilation theory posits that residential patterns, including segregation, are the result of economic, human, and cultural capital accumulation, or the lack thereof. Increasing capital leads families to find housing in more up-scale neighborhoods, while stagnant capital accumulation keeps families in neighborhoods with fewer amenities. Segregation in the spatial assimilation model is based on the economic choices made by individuals. The fact that this leads to segregation is a consequence of the differing socioeconomic status among minority racial and ethnic groups [25-28]. In contrast, segregation in the place stratification framework is based on choices made for or against these minority groups by majority groups because of their race or ethnicity. Segregation is propagated through the household-level choices of the majority group (the white-flight phenomenon), direct actions (block-busting), or government policy (mortgage underwriting policy) [29]. While assimilation is based on economics, stratification is based on racial and ethnic prejudice. This keeps minority groups of lower socioeconomic standing in segregated neighborhoods that then become more distressed over time since these areas often experience disinvestment and the residents do not have the means to maintain the neighborhoods [24,30].

The third framework identified by Chung and Brown is the Ethnic Resurgence theory, which shares traits with the two frameworks just discussed. Like the Spatial Assimilation model, Ethnic Resurgence suggests that some segregation is the result of choices made by households in 
the segregated group, but like Place Stratification theory, these choices are based more on race and ethnicity. These choices lead to "ethnic communities" of different socioeconomic levels [24]. The fourth framework proposed by Chung and Brown is Market-Led Pluralism, which suggests that the spatial distribution and intensity of segregated areas is dependent on five types of actors in the residential market: developers, lenders, real estate agents, consumers, and local communities. These market-makers in different cities or metropolitan areas interact in different ways to create the mosaic of segregated space across the urban area.

Although these four theories help explain why residential segregation occurs, few studies have applied and examined the prevalence, let alone the causes, of segregation in American cities of the late nineteenth and early twentieth centuries. Gilliland and Olson [31] demonstrate that American cities of this timeframe have not been as well-studied as their English counterparts. Their study of segregation in 1880 Montreal shows that there were high levels of segregation by both ethnicity and occupation. Railway workers clustered near their places of work, while White Protestants and French Canadians showed high levels of segregation from each other at both the block and street-level. Interestingly, Irish Catholics were more integrated with the other two groups, likely a result of their shared heritage with both groups. In their sweeping work on segregation, Massey and Denton [4] include a survey of White/Black segregation within selected Northern and Southern cities over the course of the late nineteenth through the mid-twentieth century at the ward-level, and found generally increasing levels of segregation over time. A study using a finer level of geographic analysis conducted by Logan and colleagues [23] found that isolation and dissimilarity in ten Northern cities increased between 1880 and 1940. The authors of that study further suggest that the origins of segregation in those cities pre-date the Great Migration of Southern Blacks to the North.

These studies mostly focus on the segregation of ethnic White groups from each other, or White/Black segregation in Northern cities. Examining the historical incidence of residential segregation in an American city with three races: Whites, Blacks, and Hispanics is unique. Given the increasing importance of the Hispanic population in the United States, the origins of segregation in cities with various minority-concentrated races is an important topic that needs further analysis. Since San Antonio has been an important city in the Hispanic and specifically, the Mexican American, experience since Texas joined the United States [32], it provides an excellent study area for examining segregation in the multi-racial city. This research does so, and adds another layer to the analysis by examining the durability of segregation one hundred years after the historical year being studied (1910).

\section{Materials and Methods}

\subsection{Historical San Antonio (1910)}

In 1910, the City of San Antonio was home to 96,614 people and covered approximately 36 square miles [33]. San Antonio was the wealthiest city in Texas and ranked first in terms of population, trade, and taxable value. The economic drivers in the city included the wool district, horse market, and cattle industry. Seventy miles of electric street railways and 130 cars provided transit throughout the city [34]. Although the city covered a large land area in 1910, the built environment for downtown was only recreated for the core of the city, an approximately two square mile area where one-third of the residents lived. Historical data and Sanborn maps outside of this area are sparse, which made it difficult to recreate the urban form for the entire city in 1910. However, since the purpose of this study was to focus on the central city, and in 1910 the central city was represented by the two-square mile core that was used for the study area, the data outside of this area were not included. The year 1910 was selected as the base year to recreate San Antonio for two primary reasons. First, it is believed that ethnic and racial segregation patterns of contemporary San Antonio were established by 1910. Prior to the twentieth century, segregation by income and race was limited and Mexicans and Americans intermingled until the 1880s; however, contemporary San Antonio represents spatial ethnic and racial patterns of 1910 [35]. The data used in this study allows for this hypothesis to be tested. Second, all the data sources used to 
build the dataset aligned for this timeframe, allowing for the historical geodatabase to be created to test this hypothesis. The 1910 Jules A. Appler's General Directory and Blue Book of the City of San Antonio, also known as the city directory, was used to identify the names and addresses of residents in the city. Even though the first city directory was published in 1861, it wasn't until 1903 that the directory listed businesses and head of household by street address. To properly identify the occupant of each residential structure, a year after 1903 was the most realistic to use. Since the census data are only available every 10 years, 1910 was the first year available after the 1903 date. The city directory was used as the primary resource to identify heads of households, followed by the census since local historians use the city directory as the principal guide to determine where households lived at the time. Census data were used as a secondary resource to verify, supplement, and complete any missing city directory data. In addition, a complete set of Sanborn maps was completed in 1911-1912, which corresponds well with the 1910 census and city directory data.

The geodatabase for 1910 was created by first georeferencing the Sanborn maps to the 2014 streets and parcel shapefiles provided by the Bexar County Property Appraiser using ESRI's world imagery basemap that was updated December 2014 and provides a $0.3 \mathrm{~m}$ resolution imagery in the United States. To measure configured space and evaluate the urban form, building footprints are commonly used and the Sanborn maps provide this information. The Sanborn maps were originally developed for fire insurance purposes and are accepted as the most accurate and detailed set of maps representing the built environment in the early 1900s. Special attention was given to areas where street names or the street network changed over time and where blocks have been vacated. Once the Sanborn maps were georeferenced and projected using the NAD 1983 State Plane Texas South Central coordinate system, the Sanborns were digitized at a scale of 1:200. Separate feature classes were created for the following attributes: streets (line feature class), building footprints (polygon feature class), and blocks (polygon feature class).

The building footprints were digitized by outlining the actual living or occupied space, and porches were not included in the outline. Structures detached from the occupied spaces were not digitized, leaving out stables, outhouses, storage spaces, and any other independent structures that were not occupied living or working spaces. The land use for each building was assigned to one of the following categories: commercial, industrial, mixed use, public/institutional, and residential. Vacant structures listed in the city directory were classified according to the surrounding land uses identified on the Sanborn maps.

The city directory was used to identify the head of household for each residential property digitized on the Sanborn maps. Only the head of household for each residential unit was included in the dataset since limited information exists for each household member and head of household was a consistent unit of analysis that could be compared across all data sources. The city directory identifies Black residents and the 1910 census data were used to supplement the city directory data to identify the race of every householder. At the time, Hispanic households were not consistently identified so Hispanics were identified using Census data such as the county of origin, last name, birthplace, and ethnicity of the parents. For instance, the head of household is labeled as Hispanic if the last name is Hispanic, both parents were born in Mexico, and county of origin was listed as Mexico. There were a total of 7130 head of households identified in the study area in 1910 and race was identified for over 85 percent of the head of households.

\subsection{San Antonio 100 Years Later (2010)}

In 2010, San Antonio was home to 1,327,407 people and covered approximately 461 square miles. San Antonio is a minority-majority city with over 63 percent of the population identifying as Hispanic. The median household income of $\$ 46,317$ is more than $\$ 7000$ below the national average, and the number of persons living in poverty is slightly above 20 percent [36]. San Antonio has been ranked as one of the most residentially segregated cities in the nation [21] and spatial segregation among Hispanics is particularly high $[13,16]$. Kirwan Institute's Child Opportunity Index communicates a parallel story. 
Child opportunity, measured by health, environmental, educational, social, and economic variables, demonstrates the greatest opportunity in primarily the northern portions of San Antonio where there is a concentration of Whites and the lowest levels of opportunity for children in areas concentrated by Hispanics and Blacks [37]. In a majority-minority city of Hispanics, the nation's second largest Hispanic share of population only trailing Miami [38], addressing residential segregation becomes critical.

To answer the first research question that compares the change over time, the same approximately two square mile core of downtown San Antonio is used in 2010. However, since the central city today is much larger than a century ago, the second research question addresses how the original pattern of residential segregation is represented within today's central city. This area is defined by and contained within the Interstate 410 loop. This results in a much larger land area covering approximately 181 square miles and is home to 224,546 households.

Unfortunately, since household point data is not available for 2010, race data for the head of household were collected at the next smallest geographic scale, the census block. The 1910 data were aggregated to the 2010 census blocks to allow for a comparable unit of analysis across time periods. In the southeastern portion of the city core, the blocks were vacated for the 1968 World's Fair. The 1910 block shapefile was used to recreate the blocks in this area to represent the original built environment in 1910. The number of Whites, Blacks, and Hispanics were calculated for each block along with the percent share for each timeframe. No other races, such as Asian, were included in the analysis because of the small number of households that identify as other races.

\subsection{Residential Racial Segregation Metrics}

Residential racial segregation is multidimensional and has been measured using a variety of metrics with the most common being residential evenness by the index of dissimilarity [39]. Dissimilarity is the proportion of a race that would have to move for that race to be completely integrated with another race. This index is represented on a scale from zero to one with zero representing complete integration and one representing complete segregation $[1,19]$.

Exposure is another dimension of segregation. Both isolation, the likelihood of a race to encounter another member of their own race, and interaction, the probability that one race is in contact to another race, are two common indices used to measure exposure. Isolation is measured on a scale of zero to one with one representing the greatest isolation. Interaction consists of the same range and is interpreted as the probability that one race interacts within an area with another race. Higher values of isolation and lower values of interaction imply more residential segregation [1]. Although not as common, other studies have incorporated metrics of centralization, which is the distance from the city center, concentration, the density of one race across the study area, and clustering, the degree to which minorities adjoin in the study area.

For this paper, the two most common degrees of residential racial segregation, evenness and exposure, were analyzed. To calculate evenness, the dissimilarly index was used in addition to the Theil's Information Theory Index $(\mathrm{H})$ since Theil's index considers multigroup calculations, all three races analyzed in this study (Black, White, and Hispanic) can be accounted for simultaneously. Theil's $\mathrm{H}$ reveals how diverse neighborhoods are compared to the overall diversity of the study area. The scale is consistent with the dissimilarity index with one representing no diversity and zero representing complete diversity. For exposure, both the most widely used isolation and interaction indices were used. To address the first research question, a statistic for each of the four indices (dissimilarity, interaction, isolation, and the Theil's index) were calculated for each of the five city core sections (refer to Figure 1) and compared between 1910 and 2010. These metrics were also repeated to address the second research question but a global score was first calculated for the entire central city and then a local score for each central city section in 2010 . The reason the city was divided in sections is because as a very divided and segregated city, areas in San Antonio are commonly referred to directionally from the urban core. For instance, west of downtown is an area commonly known as Hispanic 
with distressed neighborhoods. The city sections allow for a local analysis to better understand how residential segregation has changed in specific areas of the city.

\section{Results}

To address the first research question comparing the patterns of residential segregation in the city core from 1910 to 2010, the spatial distribution of the three races (White, Hispanic, and Black) are first mapped and displayed in Figure 1. The 1910 map exhibits the point data by householder race and the 2010 data are symbolized by the dot density method of the three races in each block. One dot is equal to one head of household. Point data are displayed instead of aggregated block data because the data mapped by blocks in this case are visually distracting since the blocks are laid out in a disorderly pattern. The city core is split into five sections (north, northeastern, southeastern, southwestern, and northwestern) by the five major historical streets that converge in the historical core (Fredericksburg Road, Broadway Street, East Commerce Street, South Flores Street, and West Commerce Street). This division allows for a finer level of analysis for residential racial segregation to be compared across time periods along historically important corridors and city sections.

In 1910, the city represents the monocentric model with commercial land uses and jobs concentrated in the central business district. Residential, primarily single-family homes, surround the central business district in all the city sections. The railroad creates divisions in the urban form within residential neighborhoods located in the northwestern and southwestern sections of the city. Figure 1 reveals that in 1910 White householders were distributed throughout the city but primarily resided in neighborhoods away from the railroad in the north, northeastern, and southeastern sections of the city. Hispanics are primarily confined to the southwestern and northwestern portions of the city and Blacks are concentrated near East Commerce Street in the eastern sections of the city near the railroad.

By 2010, there was a substantial population loss (a decline of 29.27 percent) in the city core; 7130 households in 1910 compared to 5043 households in 2010. By this time, the city has reorganized and represents the polycentric model with several major centers throughout the city and the concentration of jobs along major highway corridors. The population that remains is much more concentrated in the neighborhoods to the south and north of downtown. There is also a concentration of households in downtown that reside in multifamily developments. In the southeastern section, there is more integration of White and Hispanic households in 2010 but in the northwestern section there is a much greater concentration of Hispanic households today than in 1910. The other sections of the city are difficult to interpret due to the lack of residential population; however, it is interesting to note that the southwestern section of the city that was heavily concentrated by Hispanics in 1910 is almost entirely vacated of residential buildings and is primarily commercial. Also, Interstates 35 and 10, the two most significant highways in San Antonio that connect the city to Austin and Houston, now divide this section of the city.

Race distribution is also analyzed in the entire central city of San Antonio in 2010 due to the population loss in the city core. This larger study area helps address the second research question about how the patterns of segregation have spread over time. Although this area is much larger than the original center of the city (181 square miles compared to two square miles), it is suitable to use to analyze how segregation has changed over time since each area is a representation of the center of the city for each given timeframe. About one third of the city population resides in this area today which is approximately the same proportion in the study area used for 1910. The central city is split into the same five sections as the core using identical major roadways as boundaries but each section expands further away from the center of the city.

Figure 2 represents the centroid of each block and are classified by the dominant householder race within that block. Point data were used again instead of polygon blocks because of the visual distraction created by the data mapped by blocks. The gaps in residential population throughout the central city are primarily due to military bases, parks, and commercial areas. There are areas in the southern portion of the central city that still have undeveloped parcels as this area has seen less investment 
compared to the northern portion of the city. Whites are still dominant in the north and northeastern sections and in the urban core of the southeastern section, but there appears to be substantially more concentration today than in 1910. Hispanic householders are disproportionally concentrated in the northwestern, southwestern, and southeastern sections of the city. One noticeable difference from 1910 is that Hispanic householders are currently dispersed throughout all the other portions of the city as well but the two original Hispanic sections could likely be classified as hypersegregated today. In 1910, Black householders were predominantly located along the dividing line in the two eastern sections, which is consistent with today, the only difference is that the concentration is located further east of downtown. In summary, there is not much difference in the distribution of householder race in the city sections a century later besides the fact that the population has moved away from the city core and the racial patterns established in 1910 appear to be preserved throughout the central city in 2010.

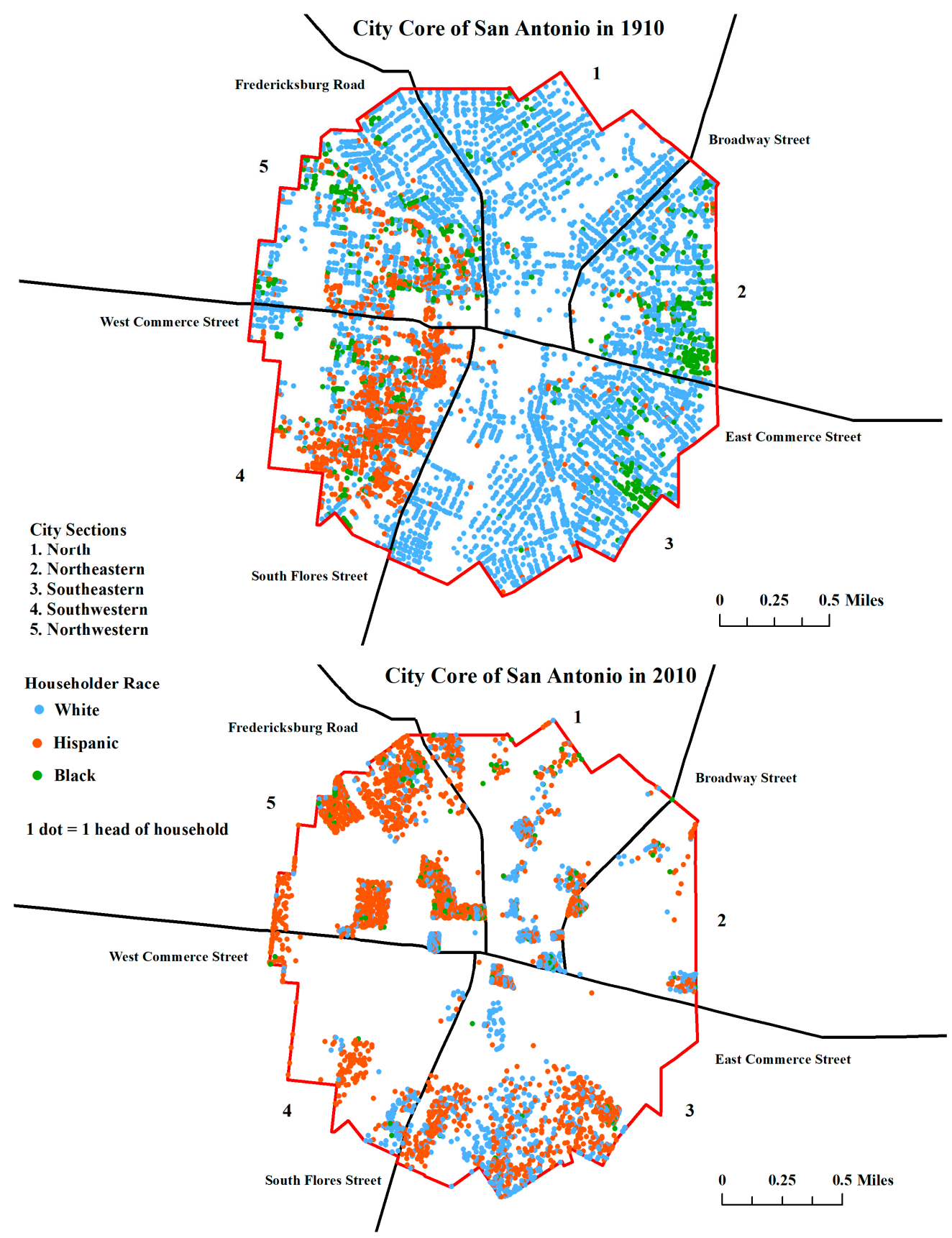

Figure 1. San Antonio's city core in 1910 and 2010 by householder race. 


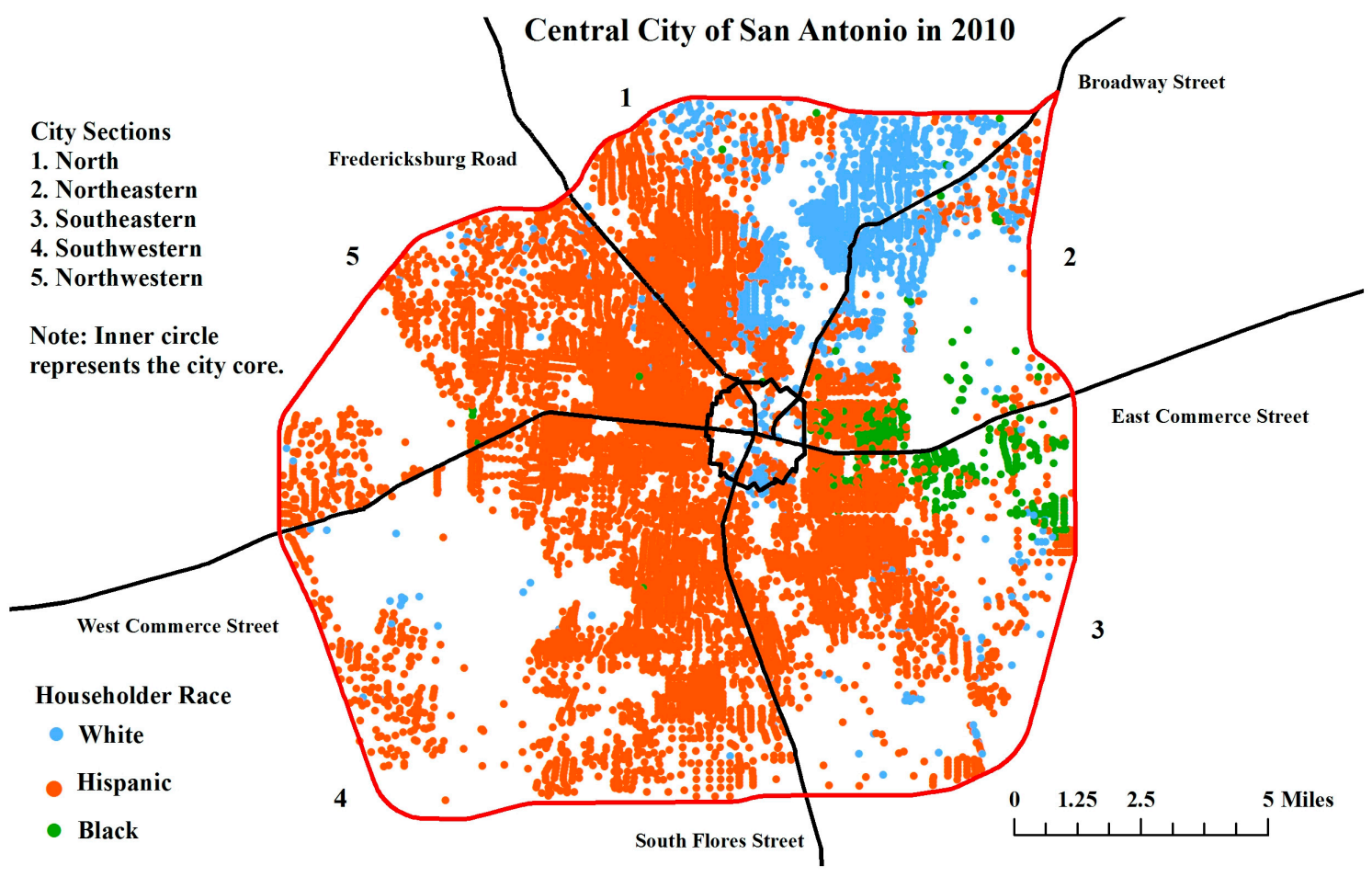

Figure 2. San Antonio's central city in 2010 by householder race.

Although there appears to be consistency in the patterns of racial distribution from 1910 to 2010, the residential racial segregation metrics are used to assess this hypothesis. The first research question is addressed by comparing the four segregation indices in the city core for 1910 and 2010. As shown in Figure 3, the dissimilarity index for each section in the city core for 1910 and 2010 reveals a higher level of segregation for every section of the city for Whites versus Black, Whites versus Hispanics, and Blacks versus Hispanics with one exception. In the southwestern section of the city, there is a higher level of segregation in 2010 of Whites compared to Hispanics. There is a small residential population in this area today, only about 257 households, and approximately 60 percent of these households are Hispanic. Although the level of segregation is overall higher in 1910, there are consistent patterns. For example, White/Black dissimilarity is relatively high in both the southeastern and northwestern sections of the city and have remained high over time; a difference of only 0.0531 and 0.0484 , respectively. These two sections also have high segregation among Whites and Hispanics and Blacks and Hispanics. The northern section of the city is the only area where segregation has declined substantially; White/Black dissimilarity has decreased by 0.2207 , White/Hispanic by 0.4413 , and Black/Hispanic by 0.5023 . The difference may be contributed to the fact that in 1910, the northern section was predominantly American and Texan born Whites with very few Hispanic and Black households. The north was buffered by White European settlers segregating American born Whites from Hispanic immigrants that settled in the west and Black households that traditionally lived closer to the central business district and service oriented occupations. 
(a) White/Black Dissimilarity

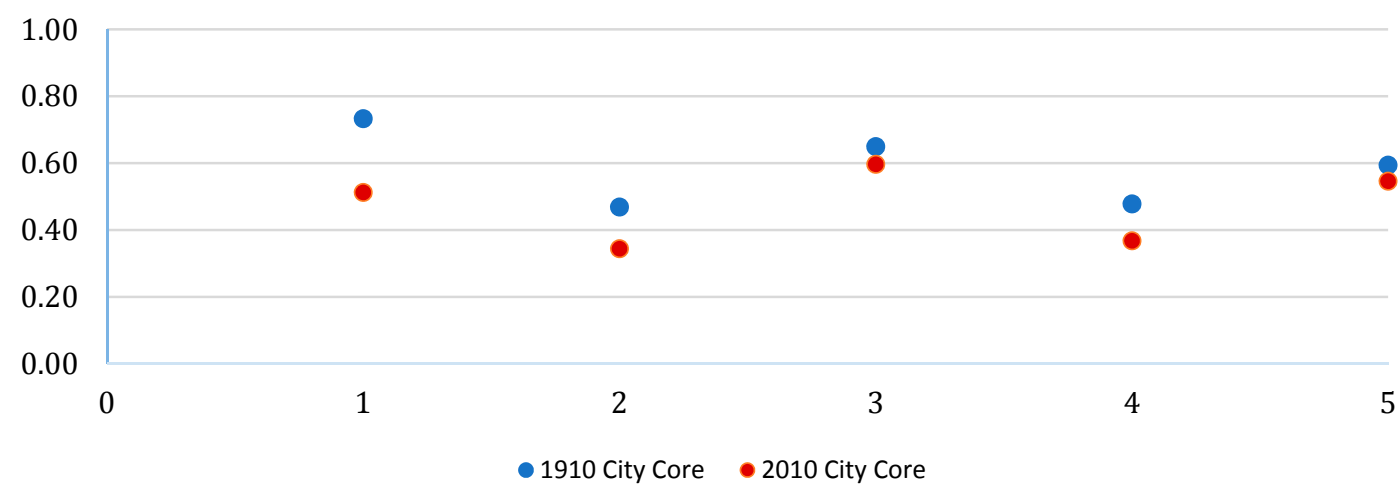

(b) White/Hispanic Dissimilarity

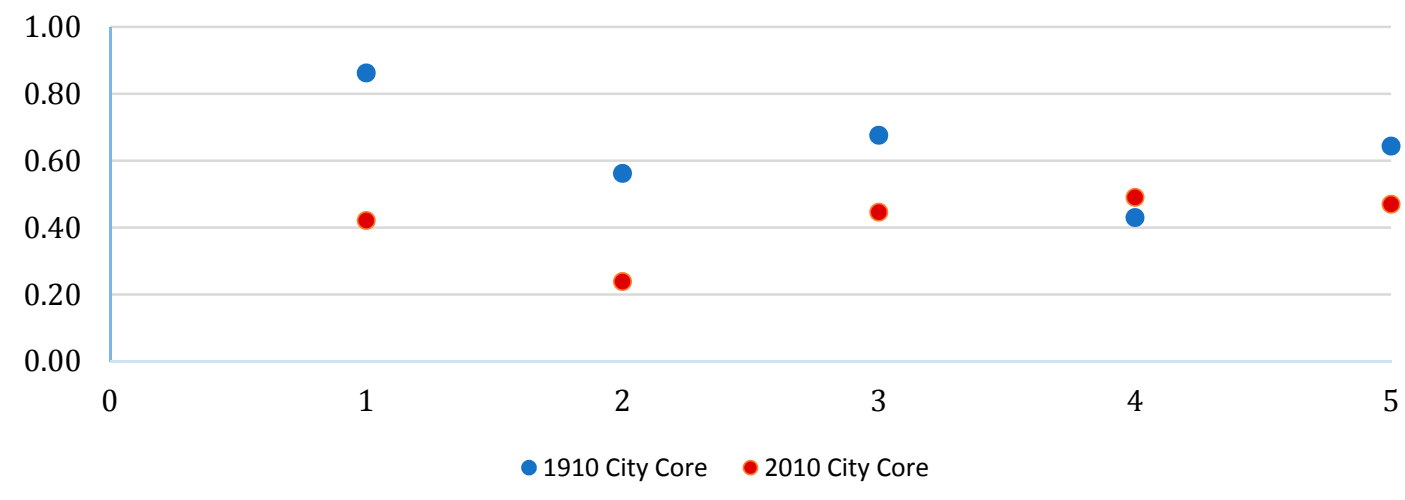

(c) Black/Hispanic Dissimilarity

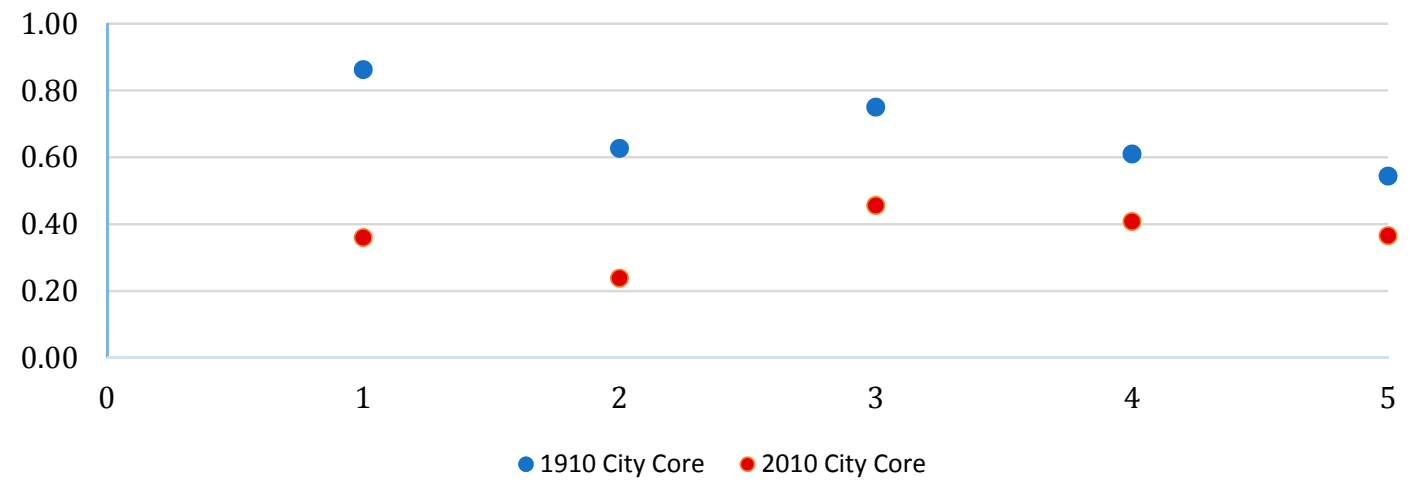

Figure 3. Dissimilarity index values for the city core sections in 1910 and 2010; (a) Description of White/Black Dissimilarity is contained in the first panel; (b) Description of White/Hispanic Dissimilarity is contained in the second panel; (c) Description of Black/Hispanic Dissimilarity is contained in the third panel.

Interaction reveals a slightly different story. As shown in Figure 4, White/Black and White/Hispanic interaction is higher in 1910 except for the southwestern section again where there is more interaction today among Whites and Blacks and Whites and Hispanics. This finding may be because many residents that live in the central core of the city today are clustered in a few neighborhoods and within multifamily developments in downtown whereas in 1910, single family residential dwellings were disbursed evenly throughout the city core (refer again to Figure 1). Conversely, Black and Hispanic interaction is much higher today in the city core than it was in 1910. Except for the southwestern section, all the remaining portions of the city have seen a substantial 
increase in interaction among Black and Hispanics over time. This finding may be due to the growing Hispanic population since 1910 in areas where Blacks were historically concentrated.

(a) White/Black Interaction

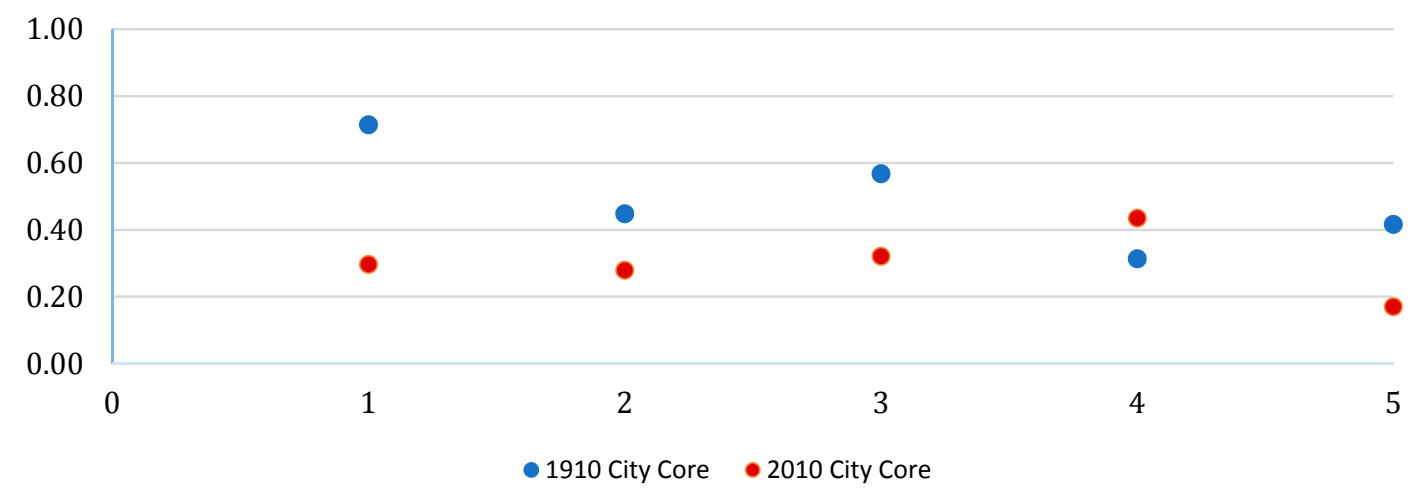

(b) White/Hispanic Interaction

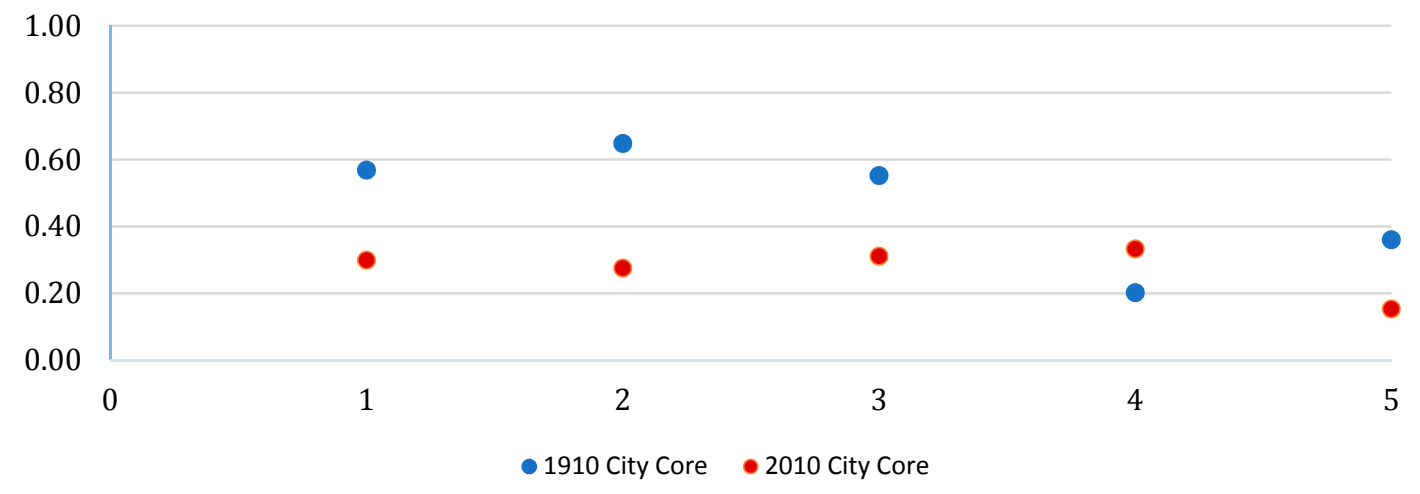

(c) Black/Hispanic Interaction

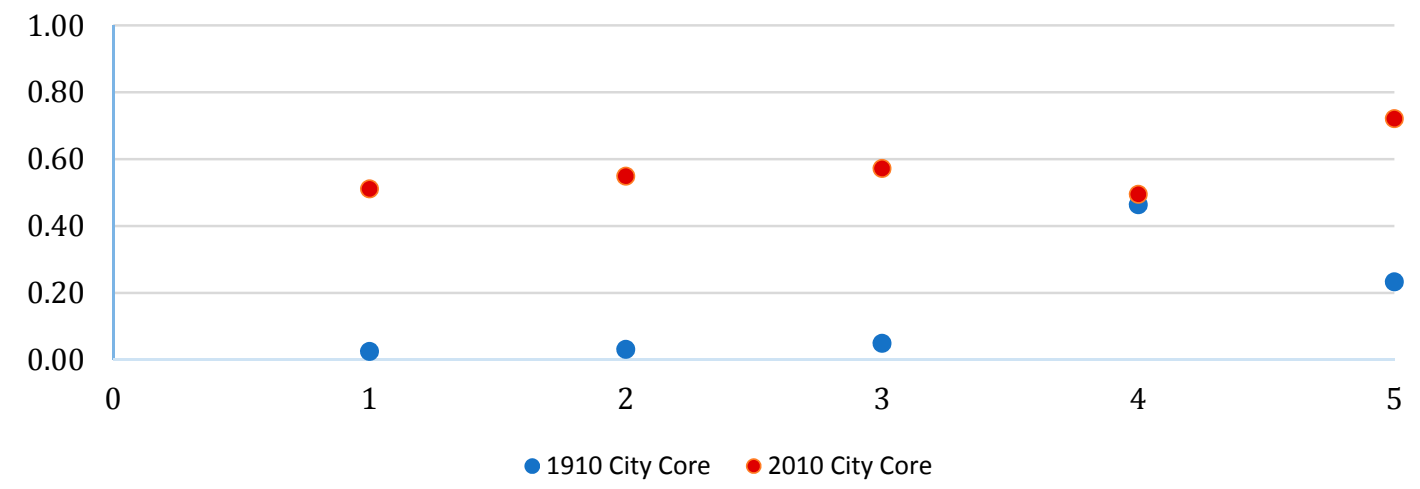

Figure 4. Interaction index values for the city core sections in 1910 and 2010; (a) Description of White/Black Interaction is contained in the first panel; (b) Description of White/Hispanic Interaction is contained in the second panel; (c) Description of Black/Hispanic Interaction is contained in the third panel.

Taking a closer look at isolation in Figure 5, Whites are more isolated than Blacks and Hispanics in both 1910 and 2010, and almost completely isolated to the northern and southeastern sections of the city in 1910 (0.9554 and 0.9002, respectively). Although Whites are the most isolated, over time this has decreased except for the southwestern portion of the city core. Blacks are the least likely to be isolated in all portions of the city and have become even less isolated over time but this may be 
because Blacks only account for approximately ten percent of all households in 1910 and 14 percent of all households in 2010. Hispanic households have become more isolated in 2010, especially in the northeastern section of the city. Again, the only exception to this pattern is the southwestern section.

(a) White Isolation

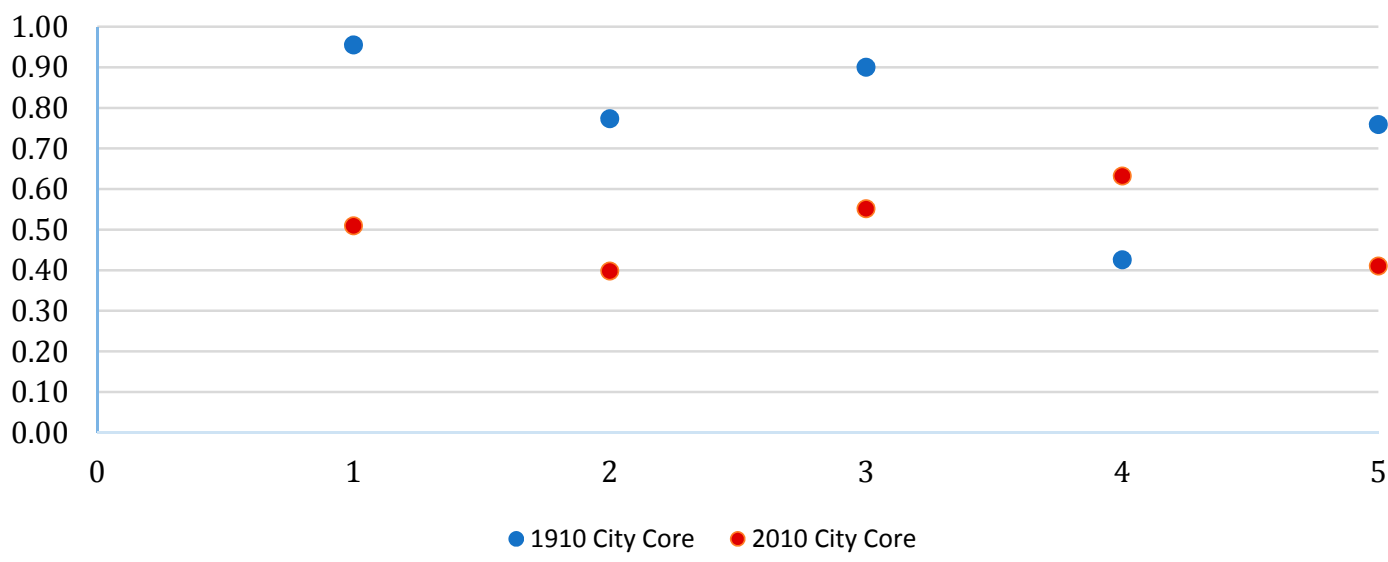

(b) Black Isolation

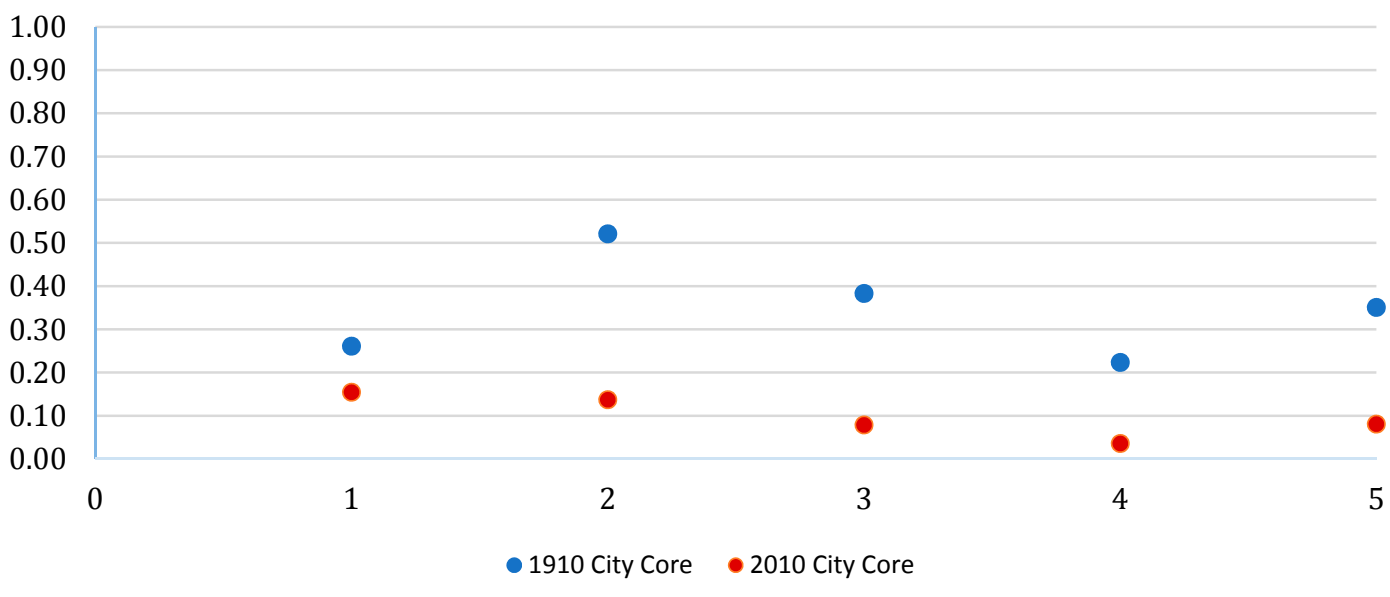

(c) Hispanic Isolation

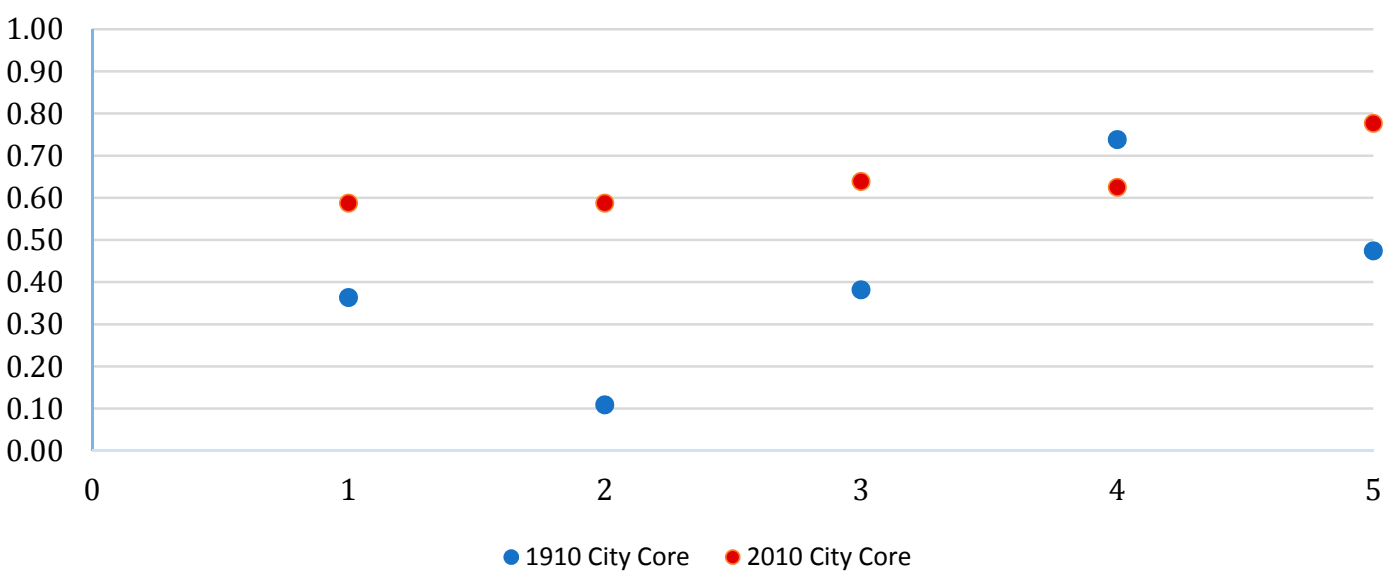

Figure 5. Isolation index values for the city core sections in 1910 and 2010; (a) Description of White Isolation is contained in the first panel; (b) Description of Black Isolation is contained in the second panel; (c) Description of Hispanic Isolation is contained in the third panel. 
The Theil's index conveys a pattern of greater diversity in 2010 than 1910 across all sections in the city core as shown in Figure 6. In fact, the north and northeastern portions of the city have become substantially more diverse over time (decreases of 0.6991 and 0.4769 , respectively). In 1910, the north and southeastern sections of the city, where Whites were the most isolated, had the least diversity. Today, the southeastern section remains the least diverse but the northern section has become one of the most diverse. The only section in the city that has seen almost no change in terms of diversity is again the southwestern section.

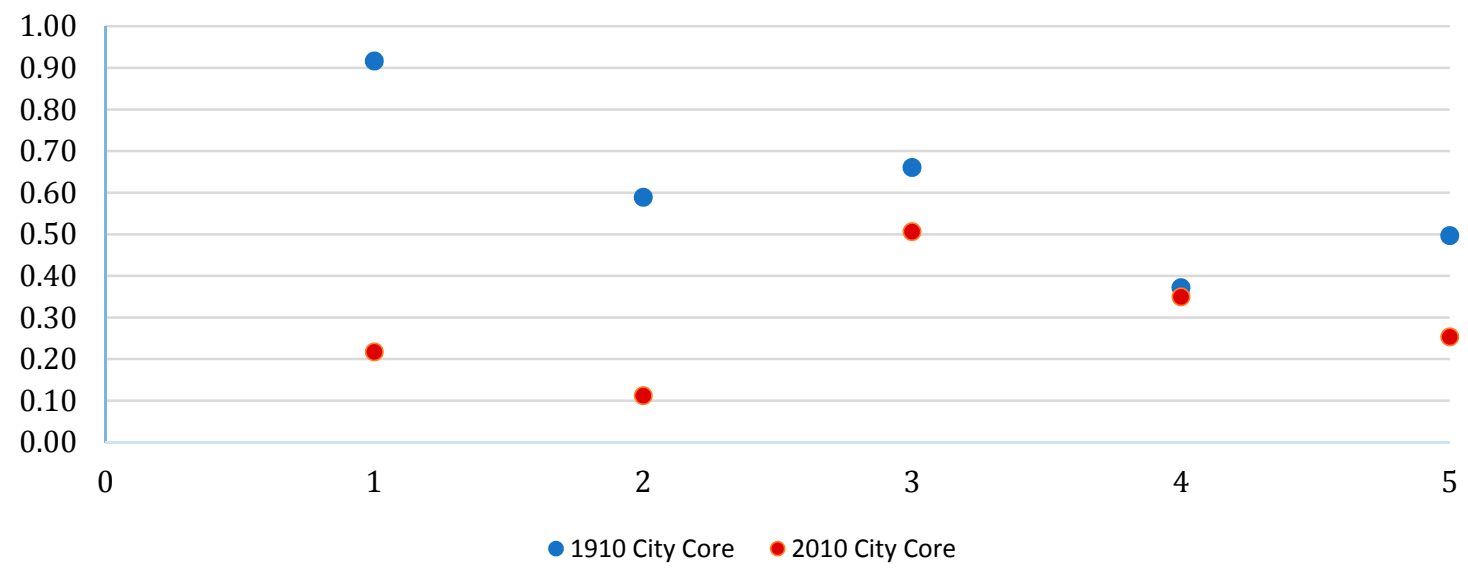

Figure 6. Theil's index values for the city core sections in 1910 and 2010.

To address the second research question regarding how the original patterns of segregation are resembled throughout today's central city, the four indices were calculated for the entire central city for 2010 (the 181 square mile area) and compared to the two square mile core in 1910. Table 1 reveals, in terms of dissimilarity, White versus Blacks have become more segregated over time but Whites versus Hispanics and Blacks versus Hispanics have become less segregated over time although the segregation levels for all three are still considerably high and consistent with other literature classifying San Antonio as an extremely residentially segregated city. Consistent with the dissimilarity index, interaction among Whites and Blacks and Whites and Hispanics has fallen over time and is noticeably low. Black and Hispanic interaction has increased but was considerably low in 1910. In terms of isolation, Whites were the most isolated in 1910 but by 2010 Hispanics have become the most isolated group. There has been relatively little change, a slight decrease, among Black isolation over the last century. The Theil's index has remained fairly stable with diversity improving only slightly over time.

Table 1. Residential racial segregation scores for the central city in 1910 and 2010.

\begin{tabular}{ccc}
\hline & $\mathbf{1 9 1 0}$ & $\mathbf{2 0 1 0}$ \\
\hline Dissimilarity & & \\
White/Black & 0.6799 & 0.7169 \\
White/Hispanic & 0.7744 & 0.5408 \\
Black/Hispanic & 0.7231 & 0.6926 \\
\hline Interaction & & \\
White/Black & 0.4207 & 0.1422 \\
White/Hispanic & 0.2613 & 0.1355 \\
Black/Hispanic & 0.1680 & 0.4758 \\
\hline Isolation & & \\
White & 0.8259 & 0.4646 \\
Black & 0.4113 & 0.3614 \\
Hispanic & 0.6590 & 0.8092 \\
\hline Theil's Index & 0.6677 & 0.6003 \\
\hline
\end{tabular}


Taking a closer look at how segregation patterns have spread throughout the city sections, Table 2 reveals that segregation has declined since 1910 in the northern section of the city when considering White/Black, White/Hispanic, and Black/Hispanic dissimilarity. Conversely, interaction has decreased among Whites and Blacks and Whites and Hispanics; however, Black and Hispanic interaction has increased over time. In 1910, Whites were the most isolated in the north but by 2010 Hispanics have become more isolated. The most dramatic change is revealed in the Theil's index with the level of diversity substantially improving in this area over time. Although there is more diversity in the northern section of the central city compared to a century ago, segregation is still high and is perpetuated throughout this area.

Table 2. Residential racial segregation scores for the northern section.

\begin{tabular}{ccc}
\hline Section 1 (North) & $\mathbf{1 9 1 0}$ & $\mathbf{2 0 1 0}$ \\
\hline Dissimilarity & & \\
White/Black & 0.7327 & 0.6794 \\
White/Hispanic & 0.8626 & 0.5211 \\
Black/Hispanic & 0.8628 & 0.6100 \\
\hline Interaction & & \\
White/Black & 0.7147 & 0.3347 \\
White/Hispanic & 0.5679 & 0.2682 \\
Black/Hispanic & 0.0246 & 0.4779 \\
\hline Isolation & & \\
White & 0.9554 & 0.6022 \\
Black & 0.2608 & 0.1493 \\
Hispanic & 0.3637 & 0.6787 \\
\hline Theil's Index & 0.9165 & 0.5668 \\
\hline
\end{tabular}

As shown in Table 3, the northeastern section, which was much less segregated than the northern section in 1910, has become more segregated over time in terms of White/Black dissimilarity but less in terms of White/Hispanic and Black/Hispanic dissimilarity. Isolation and interaction are also mixed depending on what race is considered. White/Black and White/Hispanic interaction has decreased over time while Black/Hispanic interaction has slightly improved. Whites were the most isolated in the northeast in 1910 and remain the most isolated today although Hispanic isolation has substantially increased. Again, diversity has improved although the Theil's index shows only a slight improvement a century later.

Table 3. Residential racial segregation scores for the northeastern section.

\begin{tabular}{ccc}
\hline Section 2 (Northeastern) & $\mathbf{1 9 1 0}$ & $\mathbf{2 0 1 0}$ \\
\hline Dissimilarity & & \\
White/Black & 0.4687 & 0.6992 \\
White/Hispanic & 0.5622 & 0.4800 \\
Black/Hispanic & 0.6272 & 0.4685 \\
\hline Interaction & & \\
White/Black & 0.4481 & 0.1654 \\
White/Hispanic & 0.6480 & 0.2686 \\
Black/Hispanic & 0.0310 & 0.3732 \\
\hline Isolation & & \\
White & 0.7734 & 0.5932 \\
Black & 0.5209 & 0.4304 \\
Hispanic & 0.1089 & 0.5158 \\
\hline Theil's Index & 0.5889 & 0.4424 \\
\hline
\end{tabular}


Moving on to the southeastern section of the city, Table 4 reveals White/Black dissimilarity is perpetuated through this area and has become slightly more segregated over time. Black/Hispanic and White/Hispanic dissimilarity was very high in 1910 and have become less segregated for Blacks/Hispanics and Whites/Hispanics. Interaction has only improved among Blacks and Hispanics with White/Black and White/Hispanic interaction decreasing substantially. In 1910, Whites were extremely isolated in this area but by 2010 Hispanics have become the most isolated race. Once again, the Theil's index reveals diversity has improved over time in the central city but only slightly.

Table 4. Residential racial segregation scores for the southeastern section.

\begin{tabular}{ccc}
\hline Section $\mathbf{3}$ (Southeastern) & $\mathbf{1 9 1 0}$ & $\mathbf{2 0 1 0}$ \\
\hline Dissimilarity & & \\
White/Black & 0.6492 & 0.6929 \\
White/Hispanic & 0.6762 & 0.3935 \\
Black/Hispanic & 0.7503 & 0.6585 \\
\hline Interaction & & \\
White/Black & 0.5683 & 0.1006 \\
White/Hispanic & 0.5521 & 0.1460 \\
Black/Hispanic & 0.0490 & 0.4259 \\
\hline Isolation & & \\
White & 0.9002 & 0.2905 \\
Black & 0.3827 & 0.4600 \\
Hispanic & 0.3822 & 0.7557 \\
\hline Theil's Index & 0.6605 & 0.5217 \\
\hline
\end{tabular}

Table 5 indicates that the southwestern section of the central city, the outlier of the city core analysis, is also quite different than the other sections of the central city. Segregation has increased since 1910, with higher White/Black, White/Hispanic, and Black/Hispanic dissimilarity values in 2010. Interaction among races has decreased with the expectation of Black/Hispanic interaction which has substantially risen. In 1910, Hispanics were the most isolated in this area of the city and this has remained consistent with Hispanics becoming almost entirely isolated by 2010 (an index score of 0.9095). This is the only section of the city that the Theil's index indicates less diversity over time.

Table 5. Residential racial segregation scores for the southwestern section.

\begin{tabular}{ccc}
\hline Section $\mathbf{4}$ (Southwestern) & $\mathbf{1 9 1 0}$ & $\mathbf{2 0 1 0}$ \\
\hline Dissimilarity & & \\
White/Black & 0.4777 & 0.6665 \\
White/Hispanic & 0.4298 & 0.4733 \\
Black/Hispanic & 0.6102 & 0.7488 \\
\hline Interaction & & \\
White/Black & 0.3134 & 0.1232 \\
White/Hispanic & 0.2018 & 0.0695 \\
Black/Hispanic & 0.4635 & 0.7570 \\
\hline Isolation & & \\
White & 0.4262 & 0.2102 \\
Black & 0.2231 & 0.1011 \\
Hispanic & 0.7383 & 0.9095 \\
\hline Theil's Index & 0.3714 & 0.6352 \\
\hline
\end{tabular}

The northwestern section of the central city, as shown in Table 6, has become slightly less segregated in terms of White/Black and White/Hispanic dissimilarity, with the index score for Black/Hispanic dissimilarity only slightly increasing by 2010. Interaction has decreased since 1910 
between Whites and Blacks and Whites and Hispanics in this area, but Black/Hispanic interaction has improved substantially. Whites were the most isolated race in the northwest in 1910 and today Hispanics have become the most isolated. The Theil's index reveals a slight increase in diversity over time.

Table 6. Residential racial segregation scores for the northwestern section.

\begin{tabular}{ccc}
\hline Section 5 (Northwestern) & $\mathbf{1 9 1 0}$ & $\mathbf{2 0 1 0}$ \\
\hline Dissimilarity & & \\
White/Black & 0.5939 & 0.5789 \\
White/Hispanic & 0.6437 & 0.4409 \\
Black/Hispanic & 0.5442 & 0.5599 \\
\hline Interaction & & \\
White/Black & 0.4168 & 0.1175 \\
White/Hispanic & 0.3601 & 0.1067 \\
Black/Hispanic & 0.2328 & 0.7265 \\
\hline Isolation & & \\
White & 0.7592 & 0.2546 \\
Black & 0.3504 & 0.1383 \\
Hispanic & 0.4743 & 0.8461 \\
\hline Theil's Index & 0.4966 & 0.4663 \\
\hline
\end{tabular}

\section{Discussion}

In summary, the findings reveal a consistent residential racial pattern as the city core expands over the last century. By 1910, San Antonio is already a very segregated city and this pattern has been perpetuated throughout the last century. The approximately two square mile city core has become slightly less segregated and more diverse over time with lower dissimilarity and Theil's index scores. Although the interaction index scores are lower in 2010, this may be a result of population loss and reconfiguration of residential households over the last one hundred years. In 1910, households were very evenly distributed in predominantly single family homes throughout the city core whereas today there are only a few residential neighborhoods and large multifamily buildings disbursed throughout primarily commercial uses. Whites were the most isolated in 1910, especially in the northern section of the city core, and over time, even though White isolation remains high, Hispanic isolation has noticeably increased. The southwestern section of the city core is an exception; not only is there more segregation today but very little change in diversity has occurred since 1910 in this portion of the city core.

The historical patterns of segregation in the city core are resembled throughout today's central city. Although there is less segregation and slightly more diversity, the overall residential racial segregation metrics are still high. Hispanics have become more isolated than Whites over time. The most notable results are in the southwestern portion of the city that has become less diverse and significantly more segregated over time. Over 89 percent of the households in this section of the central city are Hispanic. This area has been commonly recognized for having very poor socioeconomic conditions and decades of disinvestment.

Historical documentation can help provide insight on the factors that created the original patterns of Hispanic segregation in southwestern San Antonio. The existence of a Spanish caste system where Canary Islanders saw Native Americans, Spaniards born in Mexico, and Spaniards of mixed heritage as less Spaniard, led to the segregation among Hispanic groups and to the creation of Villa de San Fernando on the western side of the city [40-42]. The decline in socioeconomic standing of Hispanics after the transition of Texas into the Union, and the emancipation of African Americans in the South, provide the context necessary to explain it. Both groups were in the lower ranks of society after the Civil 
War, which meant that they held low paying occupations and unstable employment, limiting them to areas that they could afford or were considered undesirable by wealthier White residents [40,43].

The arrival of the railroad in the late 1870s and early 1880s from Galveston was instrumental in transforming the urban morphology of San Antonio and increasing its status as a population center. Despite its late and slow arrival, it completely changed the viability of the city and positioned it at the center of the east to west traffic of the southern half of the country, and later as the gateway for all rail traffic coming from Mexico. This created opportunities for farmers who could now haul their harvest to other markets, but also for ranchers who could carry their cattle to railheads in Kansas [32]. This was a strong factor that contributed to the end of the cattle drives in Texas, but at the same time, it helped lure the army back into the city. With the destruction of Galveston during the hurricane of 1900, the railroad turned San Antonio into a true urban center with reliable transportation [44].

However, the railroad also reshaped the urban landscape and influenced the direction of suburbanization, land values, location of industries, and therefore the spatial assortment of residents. Nineteenth century railroads were dangerous coal fired vehicles that were dirty and noisy. Only the poor resided near the railroads which created two long corridors of undesirable land uses on the west and east sides of downtown and divided the city. The wealthy elites migrated north of town on Broadway towards Fort Sam Houston enticed by advertisements for northern neighborhoods as the only place in the city where one could make it home from downtown without crossing a railroad [35].

The streetcar system benefited from the growth of economic activity in the downtown area from the arrival of new residents and tourists created by the railroad. The early lines ran in a north to south direction, causing property values where the lines were constructed to increase, and for new housing developments, that at the time were on the outskirt of town, to become accessible. With the creation of new desirable areas in the northern portions of the city, and the hustle and bustle of the downtown and businesses along the east/west corridors brought on by the railroad, the newly built communities became desirable places for wealthier families, while the surrounding neighborhoods of the core were now affordable for working class residents. This urban transformation opened the door for early African American communities such as Newcombville and the Baptist settlement to locate near downtown [40].

Local politics reordered the urban space and the southwest side became an area for Mexican immigrants to settle. The first ordinance that reinforced emerging land use patterns was adopted in 1889 which moved vice related activities such as brothels and gambling to the west side of downtown. This caused vice activities to no longer be intermingled with other downtown activities and this clustering branded the west side as a less desirable area. Large homes were turned into brothels and wealthy residents moved north. This was reinforced by another ordinance established in the early twentieth century that required all slaughter houses to be moved to the southwest side of town. Logically, these businesses clustered close to the railroad since it was their lifeline, which further contributed to undesirable uses [35].

To understand the perpetuation of segregation in southwestern San Antonio, it is vital to consider the immigration patterns between the United States and Latin America throughout the twentieth century. The Mexican Revolution of 1910 led to internal displacement of Mexicans and their arrival in San Antonio and many other cities in the Southwest. Labor shortages during both World Wars also meant that United States farmers and manufacturers needed to rely on Mexican labor and often recruited directly from Mexico or by passing temporary work authorization arrangements such as the Bracero Program [45]. With the continued flow of Mexicans and other immigrant groups from Latin America, especially from Central American countries in the 1980s and 1990s, like northern cities that saw the formation of ethnic neighborhoods with the arrival of European immigrants, the southwestern sector of San Antonio, also known as the West Side Barrio or Mexican Quarter, developed into a place of employment, social networking, a cultural heaven, and a transnational place. Consequently, ethno-racial communities are a safety net for groups in society that have been intentionally excluded or are seeking a transition into the dominant host society. 
Both past and current federal housing policies have been linked to the perpetuation of residential segregation including the Federal Housing Administration and New Deal $[9,46]$, public housing $[8,47]$, Housing Choice Voucher program [48,49], and the Low-Income Housing Tax Credit program [50,51] and this is seen in San Antonio. Until recently, federally assisted housing has been built in high poverty minority concentrated neighborhoods to the east of downtown where Blacks have historically settled and currently reside, and in Hispanic neighborhoods south and west of downtown. Steering and predatory lending has also been found to contribute to residential segregation [11] as well as land use and zoning practices [10,52]. Lending practices and federally supported policies have specifically perpetuated segregation in minority-concentrated communities in the southwestern and southeastern sections of San Antonio. The Home Owners' Loan Corporation city surveys of San Antonio during 1935 and 1936 are coded based on levels of security for real estate investment. The entire west side that is primarily occupied by Hispanics and east side where Blacks are concentrated is coded as red which represented a lending hazard and led to years of disinvestment in these neighborhoods.

This study provides insight on the historic roots of modern segregation in the southwestern cosmopolis of San Antonio, currently one of the most residentially segregated cities in the nation. It contributes to the literature by uncovering the patterns of residential segregation in 1910 in a city that has limited historical data and information on how decisions of the past have had long-term consequences on the urban landscape and has led to an entire quadrant of the city suffering from blight and disinvestment a century later. As a next step, the historical geodatabase and findings produced by this study present an opportunity to conduct a richer historical and sociological analysis on the origins of Hispanic segregation in San Antonio and the factors that have contributed to its perpetuation over time. With the increasing dispersion of the Latino community away from the Southwest U.S. into states such as North Carolina, Georgia, and Louisiana, and especially for future generations who are growing up in Latino enclaves, more research on the formation, perpetuation, and evolution of these communities is called for.

Acknowledgments: This project was funded in-part by the University of Texas at San Antonio, Office of the Vice President for Research.

Author Contributions: Rebecca J. Walter, Nathan Foote, and Hilton A. Cordoba conceived and designed the experiments; Corey Sparks performed the experiments; Rebecca J. Walter and Corey Sparks analyzed the data; and Rebecca J. Walter, Nathan Foote, and Hilton A. Cordoba wrote the paper.

Conflicts of Interest: The authors declare no conflict of interest. The founding sponsors had no role in the design of the study; in the collection, analyses, or interpretation of data; in the writing of the manuscript, and in the decision to publish the results.

\section{References}

1. Massey, D.; Denton, N. The Dimensions of Residential Segregation. Soc. Forces 1988, 67, 281-315. [CrossRef]

2. Charles, C.Z. The Dynamics of Racial Residential Segregation. Ann. Rev. Sociol. 2003, 29, 167-207. [CrossRef]

3. Galster, G. Residential Segregation and Interracial Economic Disparities: Simultaneous-Equations Approach. J. Urban Econ. 1987, 21, 22-44. [CrossRef]

4. Massey, D.; Denton, N. American Apartheid: Segregation and the Making of the Underclass; Harvard University Press: Cambridge, MA, USA, 1993.

5. Ovadia, S. The Dimensions of Racial Inequality: Occupational and Residential Segregation across Metropolitan Areas in the United States. City Community 2003, 2, 313-333. [CrossRef]

6. Von Lockette, N.D. The Impact of Metropolitan Residential Segregation on the Employment Chances of Blacks and Whites in the United States. City Community 2010, 9, 256-273. [CrossRef]

7. Wilson, W.J. The Truly Disadvantaged: The Inner City, the Underclass, and Public Policy; University of Chicago Press: Chicago, IL, USA, 1987.

8. Goering, J. Housing Desegregation and Federal Policy; UNC Press: Chapel Hill, NC, USA, 1986.

9. Jackson, K. Crabgrass Frontier: The Suburbanization of the United States; Oxford University Press: New York, NY, USA, 1985. 
10. Resseger, M. The Impact of Land Use Regulation on Racial Segregation: Evidence from Massachusetts Zoning Borders; Harvard University: Boston, MA, USA, 2013.

11. Turner, M.A.; Ross, S.; Galster, G.; Yinger, J. Discrimination in Metropolitan Housing Markets: National Results from Phase I HDS 2000; U.S. Department of Housing and Urban Development: Washington, DC, USA, 2002.

12. Logan, J.; Zhang, W.; Turner, R.; Shertzer, A. Creating the Black Ghetto: Black Residential Patterns before and during the Great Migration. Ann. Am. Acad. Political Soc. Sci. 2015, 660, 18-35. [CrossRef] [PubMed]

13. Massey, D.; Denton, N. Hypersegregation in US Metropolitan Areas: Black and Hispanic Segregation along Five Dimensions. Demography 1989, 26, 373-391. [CrossRef] [PubMed]

14. Ellen, I.G.; Steil, J.P.; De la Roca, J. The Significance of Segregation in the 21st Century. City Community 2016, 15, 8-13. [CrossRef]

15. Flippen, C.A. The More Things Change the More They Stay the Same: The Future of Residential Segregation in America. City Community 2016, 15, 14-17. [CrossRef]

16. Jones, R. The Segregation of Ancestry Groups in San Antonio. Soc. Sci. J. 2003, 40, 213-232. [CrossRef]

17. Logan, J.R. The Persistence of Segregation in the 21st Century Metropolis. City Community 2013, 12, 160-168. [CrossRef] [PubMed]

18. Timberlake, J.M.; Iceland, J. Change in Racial and Ethnic Residential Inequality in American Cities, 1970-2000. City Community 2007, 6, 335-365. [CrossRef]

19. Denton, N. Interpreting U.S. Segregation Trends: Two Perspectives. City Community 2013, 12, $156-159$. [CrossRef]

20. Lichter, D.; Parisi, D.; Taquino, M. Spatial Assimilation in U.S. Cities and Communities? Emerging Patterns of Hispanic segregation from Blacks and Whites. Ann. Am. Acad. Political Soc. Sci. 2015, 660, 36-56. [CrossRef]

21. Fry, R.; Taylor, P. The Rise of Residential Segregation by Income; Pew Research Center: Washington, DC, USA, 2012.

22. Gotham, K.F. Urban Space, Restrictive Covenants and the Origins of Racial Residential Segregation in a US City, 1900-50. Int. J. Urban Reg. Res. 2000, 24, 616-633. [CrossRef]

23. Logan, J.; Zhang, W.; Chunyu, M. Emergent Ghettos: Black neighborhoods in New York and Chicago, 1880-1940. Am. J. Sociol. 2015, 120, 1055-1094. [CrossRef] [PubMed]

24. Chung, S.; Brown, L. Racial/Ethnic Residential Sorting in Spatial Context: Testing the Explanatory Frameworks. Urban Geogr. 2007, 28, 312-339. [CrossRef]

25. Massey, D. Ethnic Residential Segregation: A Theoretical Synthesis and Empirical Review. Sociol. Soc. Res. 1985, 69, 315-350.

26. Massey, D. Segregation and Stratification. A Biosocial Perspective. DuBois Rev. Soc. Sci. Res. Race 2004, 1, 1-19. [CrossRef]

27. Massey, D.; Denton, N. Spatial Assimilation as a Socioeconomic Process. Am. Sociol. Rev. 1985, 50, 94-105. [CrossRef]

28. Massey, D.; Mullan, B. Processes of Hispanic and Black Spatial Assimilation. Am. J. Sociol. 1984, 89, 836-873. [CrossRef]

29. Alba, R.D.; Logan, J.R. Minority Proximity to Whites in Suburbs: An Individual-Level Analysis of Segregation. Am. J. Sociol. 1983, 98, 1388-1427. [CrossRef]

30. Goldsmith, P.R. Perpetuation Theory and the Racial Segregation of Young Adults. Soc. Sci. Res. 2016, 56, 1-15. [CrossRef] [PubMed]

31. Gilliland, J.; Olson, S. Residential Segregation in the Industrializing City: A Closer Look. Urban Geogr. 2010, 31, 29-58. [CrossRef]

32. Arreola, D. The Mexican American Cultural Capital. Geogr. Rev. 1987, 77, 17-34. [CrossRef]

33. Population of the 100 Largest Urban. Places: 1910; U.S. Census Bureau: Washington, DC, USA, 1910.

34. Appler, J. San Antonio City Directory; Jules, A., Ed.; Appler Directory: San Antonio, TX, USA, 1910.

35. Johnson, D.; The University of Texas at San Antonio, San Antonio, TX, USA. Personal interview, 7 February 2017.

36. QuickFacts, San Antonio City, TexasU.S. Census Bureau: Washington, DC, USA, 2010. Available online: https: //www.census.gov/quickfacts/table/PST045214/4865000/embed/accessible (accessed on 31 May 2017).

37. Kirwan Institute for the Study of Race and Ethnicity. San Antonio-New Braunfels, TX (Metro Area) Child. Opportunity Index; Institute for Child, Youth and Family Policy, Brandeis University: Waltham, MA, USA, 2015. 
38. Brown, A.; Lopez, M.H. Ranking Latino Population's in the Nation's Metropolitan Areas; Pew Research Center: Washington, DC, USA, 2013.

39. Fischer, M. The Relative Importance of Income and Race in Determining Residential Outcomes in U.S. Urban Areas, 1970-2000. Urban Aff. Rev. 2003, 38, 669-696. [CrossRef]

40. Mason, K. African Americans and Race Relations in San Antonio Texas, 1867-1937; Garland Publishing, Inc.: New York, NY, USA, 1998.

41. Diaz, D.R. Barrio Urbanism: Chicanos, Planning, and American Cities; Routledge: New York, NY, USA, 2015.

42. Diaz, D.R.; Torres, R.D. Latino Urbanism: The Politics of Planning, and Redevelopment; University Press: New York, NY, USA, 2012.

43. Montejano, D. Anglos and Mexicans in the Making of Texas, 1836-1896; University of Texas Press: Austin, TX, USA, 1987.

44. Boryczka, R. The busiest man in town: John Hermann Kampmann and the urbanization of San Antonio, Texas, 1848-1885. Southwest. Hist. Q. 2012, 115, 329-363. [CrossRef]

45. Henderson, T.J. Beyond Borders: A History of Mexican Migration to the United States; Wiley-Blackwell: West Sussex, UK, 2011.

46. Katznelson, I. When Affirmative Action Was White: An Untold History of Racial Inequality in the Twentieth Century America; W.W. Norton: New York, NY, USA, 2005.

47. Solomon, R. Public Housing Reform and Voucher Success: Progress and Challenges; The Brookings Institute: Washington, DC, USA, 2005.

48. Hartung, J.; Henig, J. Housing Vouchers and Certificates as a Vehicle for Deconcentrating the Poor: Evidence from the Washington, D.C., Metropolitan Area. Urban Aff. Rev. 1997, 32, 403-419. [CrossRef]

49. Pendall, R. Why Voucher and Certificate Users Live in Distressed Neighborhoods. Hous. Policy Debate 2000, 11, 881-910. [CrossRef]

50. Cummings, J.; DiPasquale, D. The Low-Income Housing Tax Credit: An Analysis of the First Ten Years. Hous. Policy Debate 1999, 10, 251-307. [CrossRef]

51. Van Zandt, S.; Mhatre, P. Growing Pains: Perpetuating Inequality through the Production of Low-Income Housing in the Dallas/Fort Worth Metroplex. Urban Geogr. 2009, 30, 490-513. [CrossRef]

52. Lens, M.; Monkkonen, P. Do Strict Land Use Regulations Make Metropolitan Areas More Segregated by Income? J. Am. Plan. Assoc. 2016, 82, 6-21. [CrossRef] 